\title{
GLOSA CZĘŚCIOWO APROBUJĄCA DO WYROKU WOJEWÓdZKIEGo SĄDU AdMINISTRACYJNEGO W WARSZAWIE Z DNIA 8 CZERWCA 2018 R., SYGN. III SA/WA 2354/17
}

\begin{abstract}
Streszczenie. Glosa dotyczy budzącego wątpliwości w doktrynie problemu stosowania przepisów klauzuli przeciwko unikaniu opodatkowania w aspekcie intertemporalnym. Autor glosy nie zgadza się z przedstawionym $\mathrm{w}$ orzeczeniu poglądem, że przepisy klauzuli przeciwko unikaniu opodatkowania mogą być każdorazowo stosowane do korzyści podatkowych osiągniętych na skutek czynności podjętych w stanie prawnym sprzed nowelizacji. Rozumienie reguły międzyczasowej w ten sposób może bowiem prowadzić do prawnej rekwalifikacji na niekorzyść podatnika faktów prawnych w zamkniętych już sytuacjach prawnych, co nie daje się pogodzić z konstytucyjną zasadą nieretroakcji prawa. W opinii autora nie można in abstracto ani wykluczyć, ani dopuścić stosowania przepisów klauzuli do stanów faktycznych z elementem dawnym. Badanie dopuszczalności retrospektywnego stosowania przepisów Ordynacji podatkowej powinno się bowiem odbywać ad causam, na gruncie konkretnych stanów faktycznych.
\end{abstract}

Słowa kluczowe: ogólna klauzula przeciwko unikaniu opodatkowania, podatki, stosowanie intertemporalne

* Absolwent Wydziału Prawa i Administracji Uniwersytetu Łódzkiego, e-mail: wielec.michal@o2.pl. 
„[...] nawet, jeżeli czynności, w następstwie których powstała korzyść podatkowa, zostały podjęte przed wejściem w życie ustawy zmieniającej o.p., ale sama korzyść podatkowa powstała po wejściu w życie ww. ustawy, to czynności te mogą być również badane w aspekcie art. 119a i nast. o.p.".

\section{WPROWADZENIE}

Ustawa z dnia 13 maja 2016 r. o zmianie ustawy - Ordynacja podatkowa oraz niektórych innych ustaw ${ }^{1}$ wprowadziła do polskiego porządku prawnego klauzulę przeciwko unikaniu opodatkowania (dalej także: Klauzula).W zamyśle ustawodawcy ma ona wyznaczać podatnikom granice, w ramach których mogą podejmować działania mające na celu obniżenie ciężaru podatkowego ${ }^{2}$.

Zgodnie z normą intertemporalną zawartą w art. 7 Ustawy nowelizującej, Klauzulę stosuje się do korzyści podatkowej uzyskanej po dniu jej wejścia w życie. Niemniej jednak na gruncie tak sformułowanego przepisu międzyczasowego pojawiło się wiele problemów intertemporalnych ${ }^{3}$. Dotyczą one zwłaszcza dopuszczalności stosowania przepisów art. 119a i n. Ustawy z dnia 29 sierpnia 1997 r. - Ordynacja podatkowa ${ }^{4}$ (dalej: o.p.) do korzyści podatkowych osiągniętych już w znowelizowanym stanie prawnym, uzyskanych jednak w wyniku czynności podjętych jeszcze przed dniem wejścia w życie Ustawy zmieniającej.

Niejasne sformułowanie art. 7 Ustawy nowelizującej doprowadziło zatem do powstania stanu niepewności co do stosowania klauzuli przeciwko unikaniu opodatkowania w aspekcie intertemporalnym.

W glosowanym orzeczeniu Wojewódzki Sąd Administracyjny (WSA) w Warszawie dokonał przede wszystkim analizy działań restrukturyzacyjnych podjętych przez Skarżących na gruncie przepisów Działu IIIA o.p. „Przeciwdziałanie unikaniu opodatkowania”. Niemniej jednak zajął się także rozstrzygnięciem problemu stosowania przepisów klauzuli przeciwko

1 Dz.U. z 2016 r., poz. 846, dalej: Ustawa zmieniająca lub Ustawa nowelizująca.

2 M. Kondej, Problematyka intertemporalna stosowania klauzuli przeciwko unikaniu opodatkowania, „Przegląd Podatkowy” 2017, nr 7, s. 20.

3 Ibidem.

${ }^{4}$ Dz.U. z 2017 r., poz. 201. 
unikaniu opodatkowania do korzyści podatkowych powstałych po wejściu w życie Ustawy zmieniającej, lecz osiągniętych w wyniku czynności podjętych w stanie prawnym sprzed nowelizacji.

Glosowany wyrok zapadł na skutek skargi do Wojewódzkiego Sądu Administracyjnego w Warszawie wniesionej przez C. ${ }^{1}$ sp. z o.o. i jej wspólników - C. ${ }^{2}$ sp. z o.o. oraz trzy inne osoby fizyczne na odmowę Szefa Krajowej Administracji Skarbowej (dalej także: Organ lub Szef KAS) wydania opinii zabezpieczającej.

W dniu 30 września 2016 r. Skarżący, będący wspólnikami C. ${ }^{1}$ sp. z o.o., zwrócili się do Ministra Rozwoju i Finansów o wydanie opinii zabezpieczającej. Jej przedmiotem miała być ocena planowanej przez nich zmiany formy organizacyjno-prawnej - przekształcenie spółki z ograniczoną odpowiedzialnością w spółkę komandytową. Wspólnikami C. ${ }^{1}$ sp. z o.o. były trzy osoby fizyczne oraz C. ${ }^{2}$ sp. z o.o. W przekształconym podmiocie owe osoby fizyczne miały pełnić funkcję komandytariuszy, natomiast komplementariuszem miała być C. ${ }^{2} \mathrm{sp} . \mathrm{z}$ o.o.

Zarówno C. ${ }^{1}$ sp. z o.o., jak i C. ${ }^{2}$ sp. z o.o. powstały na skutek podziału przez wydzielenie P. sp. z o.o. Czynność ta została podjęta w 2015 r. i stanowiła rozpoczęcie działań restrukturyzacyjnych. Jej efektem było wydzielenie z P. sp. z o.o. do nowo powstałych spółek - C. ${ }^{1}$ sp. z o.o. oraz C. ${ }^{2}$ sp. z o.o., dwóch zorganizowanych części przedsiębiorstwa. Na moment przekształcenia C. ${ }^{1}$ sp. z o.o. w spółkę komandytową kapitały własne tego podmiotu miały się składać $\mathbf{w}$ przeważającej części z kapitału zapasowego powstałego w wyniku zarejestrowania podziału przez wydzielenie P. sp. z o.o. oraz zysków osiągniętych w latach ubiegłych, przekazanych lub nie na kapitały inne niż zakładowy. Czynność przekształcenia tej spółki w spółkę komandytową miała stanowić dokończenie działań restrukturyzacyjnych, które Skarżący rozpoczęli w $2015 \mathrm{r}$.

W wyniku analizy treści wniosku zgłoszonego przez Skarżących, dokumentów uzupełniających oraz dodatkowych wyjaśnień Szef Krajowej Administracji Skarbowej stwierdził, że do opisanej czynności ma zastosowanie art. 119a o.p. i odmówił wydania opinii zabezpieczającej. W uzasadnieniu swojej decyzji Organ wskazał, że mimo poddania przez Skarżącego pod jego opinię jedynie czynności polegającej na przekształceniu spółki C. ${ }^{1}$ sp. z o.o. w spółkę komandytową, w stanie faktycznym 
można wyróżnić zespół czynności w rozumieniu art. 119f $\$ 1$ o.p. prowadzący do nieopodatkowania niepodzielonych zysków wypracowanych przez P.B.C. sp. z o.o. w okresie swojej działalności (spółka, z której na skutek podziału przez wydzielenia powstała C. ${ }^{1}$ sp. z o.o.).

Z informacji przedstawionych przez Skarżących wynika, że zysk osiągany przez P.B.C. sp. z o.o. w latach 1991-2015 nie był wypłacany udziałowcom w formie dywidendy. Był on natomiast przekazywany na kapitał zapasowy tej spółki. Zdaniem Organu taka struktura kapitałów własnych nie wyklucza, że w przyszłości niepodzielony zysk P.B.C. sp. z o.o. mógłby zostać przetransferowany do jej udziałowców. Organ wskazał, że taki transfer mógłby nastąpić chociażby poprzez „przekazanie całości lub części utworzonego w omawiany sposób kapitału zapasowego na kapitał zakładowy (zwiększenie wartości nominalnej udziałów), przekształcenie przedsiębiorstwa w spółkę osobową lub jego likwidację, wskutek której następuje przekazanie udziałowcom majątku likwidowanego podmiotu”.

Zdaniem Szefa KAS transfer zysku, niezależnie od formy, w jakiej został dokonany, jest zdarzeniem podlegającym opodatkowaniu po stronie wspólnika (udziałowca), gdyż stanowi dochód w rozmienieniu Ustawy z dnia 26 lipca 1992 r. o podatku dochodowym od osób fizycznych ${ }^{5}$ (dalej: u.p.d.o.f.) lub Ustawy z dnia 15 lutego 1992 r. o podatku dochodowym od osób prawnych ${ }^{6}$ (dalej: u.p.d.o.p.). Natomiast korzyść podatkowa polegająca na nieopodatkowanym przekazaniu spółce osobowej niepodzielonych zysków jest sprzeczna zarówno z celem i przedmiotem tych ustaw podatkowych, jak i z modelem opodatkowania spółek handlowych.

Przekształcenie C. ${ }^{1}$ sp. z o.o. w spółkę komandytową oraz poprzedzające je czynności spełniały zatem, w opinii Organu, definicję czynności dokonanej przede wszystkim w celu osiągnięcia korzyści podatkowej sprzecznej w danych okolicznościach z przedmiotem i celem ustawy podatkowej (art. 119a $\$ 1$ o.p.). Dlatego też, na podstawie art. 119y $\$ 2$ o.p., Szef Krajowej Administracji Skarbowej odmówił wydania opinii zabezpieczającej, wskazując, że do opisanej czynności możliwe jest zastosowanie klauzuli przeciwko unikaniu opodatkowania.

W skardze do Wojewódzkiego Sądu Administracyjnego w Warszawie Skarżący wnieśli o uchylenie decyzji Organu i przekazanie sprawy do ponownego rozpatrzenia. Zaskarżonej odmowie zarzucili m.in. naruszenie

5 Tekst jedn. Dz.U. z 2016 r., poz. 2032.

6 Tekst jedn. Dz.U. z 2020 r., poz. 1406. 
art. 7 Ustawy zmieniającej poprzez uznanie, że działanie Skarżących podjęte przed wejściem $w$ życie przepisów art. 119a i następnych o.p. stanowią „element (dokończenie) zaplanowanego wcześniej działania” i objęte będą zakresem wskazanych przepisów.

\section{ROZSTRZYGNIĘCIE}

Wojewódzki Sąd Administracyjny w Warszawie uwzględnił żądania Skarżącego i uchylił zaskarżoną odmowę wydania opinii zabezpieczającej. Sąd nie uwzględnił jednak zarzutu dotyczącego art. 7 Ustawy zmieniającej, tj. tego, że czynności podjęte przez Skarżącego nie są objęte zakresem tego przepisu. WSA uznał za dopuszczalne badanie przesłanek warunkujących zastosowanie klauzuli przeciwko unikaniu opodatkowania także w stosunku do czynności przeprowadzonych przez Skarżących w stanie prawnym, w którym przepisy te nie obowiązywały. Wskazał, że nawet jeżeli część czynności restrukturyzacyjnych Skarżący przeprowadzili przed wejściem w życie Ustawy zmieniającej, ale sama korzyść podatkowa powstała po nowelizacji, to czynności te mogą być badane w aspekcie art. 119a i n. o.p.

4. Analiza wyroku

\subsection{Ocena rozstrzygnięcia}

Orzeczenie odpowiada prawu mimo błędnego uzasadnienia. Nie ulega bowiem wątpliwości, że po usunięciu błędów zawartych w uzasadnieniu sentencja nie uległaby zmianie.

Nie można się zgodzić z wyrażonym przez Sąd w uzasadnieniu poglądem, że „nawet, jeżeli czynności, w następstwie których powstała korzyść podatkowa, zostały podjęte przed wejściem w życie ustawy zmieniającej o.p., ale sama korzyść podatkowa powstała po wejściu w życie ww. ustawy, to czynności te mogą być również badane w aspekcie art. 119a i nast. o.p.” Taka wykładnia normy intertemporalnej jest nieprawidłowa. Za błędne należy uznać założenie, że reguła międzyczasowa pozwala na uniwersalne stosowanie klauzuli przeciwko unikaniu opodatkowania do wszystkich korzyści podatkowych uzyskanych 15 lipca 2016 r. i później, niezależnie od terminu dokonania samych czynności abuzywnych. Rozumienie normy intertemporalnej w taki właśnie sposób dopuszcza bowiem możliwość retroaktywnego stosowania przepisów art. 119a i n. o.p. Retroakcja nie 
daje się natomiast pogodzić z konstytucyjną zasadą nieretroakcji prawa oraz zasadą zaufania obywatela do państwa i wywodzoną z niej zasadą niedziałania prawa wstecz (zasady wynikające $z$ art. 2 Konstytucji Rzeczypospolitej Polskiej ${ }^{7}$, składające się na zasadę demokratycznego państwa prawnego $^{8}$ ).

4.2. Problem intertemporalny oraz sytuacja intertemporalna

Błędne uzasadnienie orzeczenia wynika niejako ze zbagatelizowania przez Sąd sytuacji intertemporalnej, zaistniałej na gruncie niniejszego stanu faktycznego. Sytuacja taka powstaje, gdy określone sytuacje prawne, które zaszły pod rządami „prawa starego”, trwają wciąż po wejściu w życie "prawa nowego"'. Sytuacja intertemporalna charakteryzuje się występowaniem pewnego elementu dawnego, czyli takiego, który zaistniał jeszcze pod rządami „prawa starego".

Wystąpienie sytuacji intertemporalnej wiąże się z zaistnieniem problemu intertemporalnego. Podmiot stosujący prawo ${ }^{10}$ staje bowiem przed problemem, który sprowadza się do rozstrzygnięcia, jakie prawo znajduje zastosowanie do sytuacji prawnej powstałej przed jego zmianą, a która nadal trwa lub wywołuje skutki prawne w chwili wejścia w życie „prawa nowego”. Podmiot taki musi zdecydować, czy do takiej sytuacji intertemporalnej zastosowanie ma „prawo nowe” czy „prawo stare”"1.

Przy wprowadzaniu zmian w prawie racjonalny ustawodawca powinien rozstrzygnąć problem intertemporalny. Zazwyczaj dokonuje tego poprzez wprowadzenie właściwej reguły międzyczasowej w obrębie „prawa nowego". Jest to z punktu widzenia nauki oraz techniki prawodawczej rozwiązanie optymalne ${ }^{12}$. To ustawodawca, stanowiąc „nowe prawo”, decyduje, czy będzie miało ono zastosowanie do sytuacji intertemporalnych czy nie.

7 Artykuł 2 Konstytucji Rzeczypospolitej Polskiej z dnia 2 kwietnia 1997 r. (Dz.U. z 1997 r., Nr 78, poz. 483), dalej: Konstytucja RP.

8 Wyrok Trybunału Konstytucyjnego (TK) z dnia 18 października 2006 r., sygn. P 27/05, LEX nr 21085.

${ }^{9}$ Problematyka intertemporalna $w$ prawie. Zagadnienia podstawowe. Rozstrzygnięcia intertemporalne. Geneza i funkcje, red. J. Mikołajewicz, Warszawa 2015, s. 153.

${ }_{10}$ Pojęcie podmiotu stosującego prawo należy w tym przypadku rozumieć szeroko.

11 Ibidem, s. 112.

12 Wyrok TK z dnia 5 grudnia 1995 r., sygn. K 6/95, LEX nr 25560. 
Niemniej jednak literalne brzmienie art. 7 Ustawy zmieniającej nie pozwala na rozstrzygnięcie, czy Klauzula znajduje zastosowanie do sytuacji intertemporalnych czy nie. Dlatego dla jej prawidłowego stosowania konieczne jest przeprowadzenie procesu wykładni.

4.3. Retroaktywność a retrospektywność

Przy dokonywaniu wykładni normy intertemporalnej istotne znaczenie ma przeprowadzenie rozróżnienia na retroakcję właściwą i retroakcję pozorną, czyli retrospektywnośćc ${ }^{13}$. Regulacja prawna ma charakter retroaktywny, jeżeli jej mocą nowe prawo jest stosowane do sytuacji prawnych mających miejsce przed jej wejściem w życie. Dotyczy to w szczególności stanów prawnych, w których początek stosowania ustawy został ustalony na moment wcześniejszy, aniżeli stała się ona obowiązująca. Retroaktywność jest niekiedy nazywana również stosowaniem wstecznym normy. Podmiot ją stosujący ocenia na jej podstawie także fakty, które zaszły przed dniem jej wejścia w życie ${ }^{14}$.

Natomiast regulacja prawna ma charakter retrospektywny, jeżeli jej mocą nowe prawo jest stosowane do sytuacji prawnych $z$ elementem dawnym, czyli do skutków prawnych faktów, które miały miejsce przed wejściem w życie ustawy, trwających stosunków prawnych oraz faktów, które zostają w części zrealizowane przed wejściem w życie nowego prawa, a w części po tym fakcie ${ }^{15}$. Retrospektywność to bezpośrednie działanie ustawy nowej. Polega ono na stosowaniu „prawa nowego” do sytuacji trwających w momencie jego wejścia w życie ${ }^{16}$.

Trybunał Konstytucyjny wskazywał, że na gruncie Konstytucji RP mamy do czynienia z „rygorystycznym, choć nie absolutnym” zakazem retroakcji ${ }^{17}$. Niemniej jednak $\mathbf{w}$ prawie daninowym ten zakaz wydaje się

13 Wyrok TK z dnia 23 kwietnia 2013 r., sygn. P 44/10, LEX nr 1311514.

14 W. Lang, Obowiązywanie normy prawnej w czasie w świetle logiki norm, Kraków 1960, s. 54.

15 H. Filipczyk, Reguła intertemporalna klauzuli ogólnej przeciwko unikaniu opodatkowania w świetle standardów konstytucyjnych, „Przegląd Podatkowy” 2016, nr 9, s. 4.

16 E. Łętowska, O potrzebie zmiany poglądów na znaczenie art. 3 k.c., [w:] Studia zzakresu prawa gospodarczego i handlowego. Ksiega pamiątkowa ku czci Profesora Stanisława Włodyki, red. W. Pyzioł i in., Kraków 1996, s. 288.

17 Na przykład wyroki TK: z dnia 14 lipca 1986 r., sygn. K 1/86, LEX nr 29399; z dnia 30 listopada 1988 r., sygn. K 1/88, LEX nr 25486. 
zbliżony do absolutnego ${ }^{18}$. Zupełnie inaczej TK odnosi się natomiast do regulacji o charakterze retrospektywnym. Uznaje on retrospekcję za dozwoloną, wskazuje jednak jej liczne wady. Zauważa, że może ona stanowić zagrożenie w postaci naruszenia zasady zaufania obywatela do państwa, zasady ochrony praw nabytych czy nieretroakcji prawa. Każdorazowe stosowania przepisów w sposób retrospekcyjny stanowi bowiem odejście od zasady pewności prawa na rzecz jego celowości i równości wobec niego. Opierając się na analizie orzecznictwa Trybunału Konstytucyjnego, można zatem dojść do przekonania, że stosowanie przepisów w sposób retrospekcyjny jest dozwolone, jeżeli:

- za bezpośrednim stosowaniem nowego prawa stoi ważny interes publiczny i nie sprzeciwiają się temu wartości konstytucyjnie chronione,

- nie narusza to zasady ochrony praw słusznie nabytych oraz

- $\quad \mathrm{u}$ adresata normy nie występowało uzasadnione oczekiwanie stabilności prawa.

Należy zatem przyjąć, że retrospekcja jest dozwolona w szerszym zakresie niż retroakcja, lecz także podlega ograniczeniom.

\subsection{Norma intertemporalna}

Artykuł 7 Ustawy zmieniającej stanowi, że przepisy art. 119a i n. o.p. mają zastosowanie do korzyści podatkowych osiągniętych po dniu wejścia w życie tejże ustawy. Ze względu na 30-dniowe vacatio legis klauzula przeciwko unikaniu opodatkowania odnosi się zatem do korzyści podatkowych uzyskanych 15 lipca 2016 r. lub później. Nie oznacza to jednak, że Klauzula znajduje automatyczne zastosowanie do wszystkich korzyści podatkowych uzyskanych po tej dacie. Przepis ten stanowi wyłącznie, że każda korzyść podatkowa uzyskana 15 lipca 2016 r. lub później może być analizowana przez organy podatkowe pod względem tego, czy są w stosunku do niej spełnione kryteria zastosowania klauzuli przeciwko unikaniu opodatkowania ${ }^{19}$.

W początkowo zgłoszonym projekcie ustawy ${ }^{20}$ przepis art. 7 brzmiał inaczej i zakładał, że klauzula przeciwko unikaniu opodatkowania będzie miała zastosowanie do „czynności” dokonanych po dniu wejścia w życie

18 Wyrok TK z dnia 2 kwietnia 2007 r., sygn. SK 19/06, LEX nr 270205.

19 M. Kondej, Problematyka intertemporalna..., s. 22.

${ }^{20}$ Rządowy projekt ustawy o zmianie ustawy - Ordynacja podatkowa oraz niektórych innych ustaw, druk sejmowy nr 367/VIII kadencja. 
Ustawy zmieniającej. Przy czym podczas prac w podkomisjach sejmowych zmodyfikowano jego pierwotne brzmienie, zastępując słowo „czynność" frazą „korzyści uzyskane”. Poprawkę umotywowano tym, że użycie w tekście ustawy terminu „czynność” uniemożliwiałoby zastosowanie Klauzuli do struktur podatkowych wdrożonych jeszcze przed nowelizacją ${ }^{21}$.

Już podczas dyskusji w komisji sejmowej pojawiły się jednak wątpliwości co do zgodności przepisu intertemporalnego z Konstytucją RP, w szczególności z konstytucyjną zasadą ochrony praw nabytych ${ }^{22}$. Ponadto wskazywano, że ze względu na krótkie vacatio legis przepis ten może naruszać zasadę ochrony interesów w toku ${ }^{23}$. Niemniej, pomimo zgłaszanych uwag, art. 7 został uchwalony w zmienionym brzmieniu.

Z treści art. 7 Ustawy zmieniającej wynika, że Klauzula może zostać zastosowana do korzyści podatkowej uzyskanej po dniu jej wejścia w życie, niezależnie od usytuowania na osi czasu samych czynności abuzywnych umożliwiających osiągnięcie tej korzyści ${ }^{24}$. O ile nie budzi wątpliwości, że na podstawie tego przepisu Klauzula może zostać zastosowana do stanów faktycznych, w których zarówno korzyść podatkowa, jak i czynność stanowiąca unikanie opodatkowania zostały dokonane po wejściu w życie Ustawy nowelizującej, o tyle, jak już wskazano wcześniej, nie jest możliwe przyjęcie, że Klauzula może być każdorazowo zastosowana także do korzyści podatkowych powstałych po tej dacie, lecz w związku z czynnościami podjętymi przed 16 lipca 2016 r. Rozumienie przepisu w taki sposób może bowiem prowadzić do prawnej rekwalifikacji na niekorzyść podatnika faktów prawnych w zamkniętych już sytuacjach prawnych, czyli do retroaktywnego stosowania prawa. Taka wykładnia nie daje się zatem pogodzić z konstytucyjną zasadą nieretroakcji prawa. Zasada ta, chociaż nie została wyrażona wprost w Konstytucji RP, stanowi istotny składnik zasady zaufania obywateli do państwa, która jest wywodzona z konstytucyjnej zasady demokratycznego państwa prawnego ${ }^{25}$.

${ }^{21}$ Retransmisja $\mathrm{z}$ posiedzenia podkomisji stałej do monitorowania systemu podatkowego z 27 kwietnia 2016 r., sejm.gov.pl; J. Gosiewski, Pisemne uzasadnienie poprawki do art. 5 ustawy o zmianie ustawy - ordynacja podatkowa oraz niektórych innych ustaw, Materiały sejmowe (niepubl.), s. 1.

22 Kancelaria Sejmu, Pełen zapis przebiegu posiedzenia Komisji Finansów Publicznych (nr 56) z 12 maja 2016 r., Biuletyn 611/VIII, Wypowiedź Włodzimierza Nykiela.

${ }^{23}$ Ibidem, Wypowiedź Sędziego NSA Artura Mudreckiego.

${ }^{24}$ H. Filipczyk, Reguła intertemporalna..., s. 7.

25 Wyrok TK z dnia 29 stycznia 1992 r., sygn. K 15/91, LEX nr 25283. 
4.5. Wykładnia normy intertemporalnej

Dokonane przez ustawodawcę rozstrzygnięcia intertemporalne muszą być zgodne z zasadą demokratycznego państwa prawnego (art. 2 Konstytucji RP $)^{26}$. O ile bezzasadna jest teza o tout court niekonstytucyjności reguły międzyczasowej zawartej w art. 7 Ustawy nowelizującej, o tyle jej rozumienie i stosowanie musi podlegać ograniczeniom narzuconym przez standardy konstytucyjne ${ }^{27}$.

Uwzględniając poczynione dotychczas uwagi dotyczące retrospektywności oraz retroaktywności norm prawych, należy wskazać, że niedopuszczalne jest przyjęcie takiej wykładni art. 7 Ustawy nowelizującej, która dopuszczałaby stosowanie przepisów art. 119a i n. o.p. w sposób retroaktywny. Problem intertemporalnego stosowania klauzuli przeciwko unikaniu opodatkowania sprowadza się zatem do rozstrzygnięcia, czy przepis międzyczasowy pozwala na stosowanie Klauzuli w sposób retrospektywny.

Do rozstrzygnięcia tego problemu niezbędne jest przeprowadzenie analizy normy intertemporalnej na gruncie wyartykułowanych przez Trybunał Konstytucyjny przesłanek retrospektywnego stosowania prawa. W mojej opinii nie można bowiem in abstracto ani wykluczyć, ani dopuścić retrospektywnego stosowania przepisów Klauzuli do stanów faktycznych z elementem dawnym, gdyż ważenie pomiędzy zasadą pewności prawa a równością wobec niego i celowością nie opiera się na żadnych stałych przesłankach i jest dokonywane ad causa ${ }^{28}$.

O ile można się zgodzić z wyrażanymi na gruncie doktryny poglądami, że za bezpośrednim stosowaniem Klauzuli do stanów faktycznych z elementem dawnym przemawia ważny interes publiczny, a u podatników nie występowało uzasadnione oczekiwanie niezmienności prawa w tym obszarze $^{29}$, o tyle niemożliwe jest przyjęcie założenia, że bezpośrednie stosowanie przepisów nie doprowadzi do skutku retroaktywnego bądź nie naruszy zasady ochrony praw słusznie nabytych. Oceny tych przesłanek należy bowiem dokonywać na gruncie konkretnych stanów faktycznych. Badanie

${ }^{26}$ H. Filipczyk, Reguła intertemporalna..., s. 5.

${ }^{27}$ Ibidem, s. 1.

${ }^{28}$ M. Kolibski, K. Turzyński, Reguła intertemporalna klauzuli ogólnej przeciwko unikaniu opodatkowania $w$ świetle standardów konstytucyjnych - polemika, „Przegląd Podatkowy" 2016, nr 12, s. 22.

29 Por. m.in. H. Filipczyk, Reguła intertemporalna..., s. 8-10. 
dopuszczalności retrospektywnego stosowania przepisów o.p. powinno być zatem zawsze dokonywane ad causam.

Konkludując powyższe rozważania, stosowanie klauzuli przeciwko unikaniu opodatkowania do stanów faktycznych z elementem dawnym należy uznać za dopuszczalne. Niemniej jednak niemożliwe jest uniwersalne wyznaczenie zakresu jej stosowania. Każdorazowo niezbędna jest analiza konkretnego stanu faktycznego w celu ustalenia, czy zastosowanie przepisów art. 119a i n. o.p. do danej sytuacji prawnej nie doprowadzi do retroakcji oraz czy nie sprzeciwia się temu zasada ochrony praw słusznie nabytych.

4.6. Zastosowanie Klauzuli na gruncie stanu faktycznego glosowanego orzeczenia

4.6.1. Uwagi ogólne

Przenosząc powyższe rozważania na grunt przedmiotowej sprawy, należy wskazać, że przyjęte przez Sąd rozumienie reguły intertemporalnej było błędne. Co za tym idzie, jej literalne brzmienie nie może być uznane za wystarczające uzasadnienie dopuszczalności zastosowania przepisów Działu IIIA o.p. na gruncie omawianej sprawy. Jak wskazano wcześniej, art. 7 Ustawy nowelizującej nie może być interpretowany w taki sposób, że dopuszcza możliwość stosowania przepisów art. 119a i n. o.p. do wszystkich korzyści podatkowych, niezależnie od usytuowania na osi czasu samych czynności abuzywnych. Stosowanie tych przepisów do korzyści podatkowych osiągniętych w związku z czynnościami podjętymi w stanie prawnym sprzed nowelizacji, czyli w sposób retrospektywny, należy uznać za dopuszczalne. Niemniej wymaga ono każdorazowo przeprowadzenia wnikliwej analizy stanu faktycznego konkretnej sprawy.

W stanie faktycznym, na gruncie którego zapadło glosowane orzeczenie, Sąd powinien zatem zbadać, czy zastosowanie przepisów znowelizowanej ustawy wprost do czynności Skarżących nie będzie miało charakteru retroaktywnego oraz czy nie naruszy praw słusznie przez nich nabytych.

4.6.2. Retrospektywny charakter zastosowania Klauzuli

Analizę stanu faktycznego omawianej sprawy należy rozpocząć od zbadania, czy zastosowanie przepisów Klauzuli wprost do czynności opisanych przez Skarżących miało charakter retroaktywnego czy retrospektywnego stosowania prawa. 
Zgodnie $\mathrm{z}$ wyrokiem Trybunału Konstytucyjnego z dnia 12 maja 2009 r. $^{30}$ retrospektywność polega na „nakazie zastosowania nowego prawa do stosunków prawnych, które wprawdzie zostały zawiązane pod rządami dawnych przepisów, ale wówczas nie zostały jeszcze zrealizowane wszystkie istotne elementy tych stosunków". Norma prawna znajduje więc zastosowanie do stosunków zaistniałych wcześniej i nadal trwają$\mathrm{cych}^{31}$. Retroaktywne stosowanie prawa ma natomiast miejsce w sytuacji, kiedy norma prawna znajduje zastosowanie do zamkniętych już stanów prawnych, które zaistniały w okresie przed jej wejściem w życie.

W ramach czynności restrukturyzacyjnych podjętych przez Skarżących na gruncie omawianego stanu faktycznego możemy wyróżnić dwa zasadnicze etapy: wydzielenie z P. sp. z o.o. do nowo powstałych spółek dwóch zorganizowanych części przedsiębiorstwa (dokonane przed wejściem w życie Ustawy zmieniającej) oraz przekształcenie C. ${ }^{1}$ sp. z o.o. w spółkę komandytową (zaplanowane). W chwili wejścia w życie Ustawy nowelizującej $w$ ramach przedmiotowego stosunku prawnego nie zostały zatem jeszcze zrealizowane wszystkie istotne jego elementy. Stosunek ten trwał nadal i nie został zakończony. Za takim poglądem przemawia również fakt, że to właśnie na ostatnim, niezrealizowanym dotychczas etapie restrukturyzacji Szef KAS upatrywał powstania korzyści podatkowej w rozumieniu art. 119 e pkt 1 o.p. ${ }^{32}$

W przedmiotowej sprawie zastosowanie przepisów Klauzuli wprost nie oddziałuje więc na kwalifikację prawną ,,zakończonych zdarzeń”, „,zamkniętych stanów faktycznych", które zaistniały przed jej wejściem w życie, czy też „wygasłych stosunków prawnych" ${ }^{33}$. Przepisy te nie odnoszą skutku prawnego wobec czynności już zakończonych (zawiązania C. ${ }^{1}$ sp. z o.o. oraz podziału przez wydzielenie P. sp. z o.o.). Kształtują wyłącznie pro futuro skutki prawne zastanej sytuacji prawnej, które wciąż trwają (pozostawanie niepodzielonego zysku w ramach kapitałów własnych C. ${ }^{1}$ sp. z o.o.).

30 Sygn. P 66/07, LEX nr 511940.

31 Zob. np. wyroki TK: z dnia 31 stycznia 1996 r., sygn. K 9/95; z dnia 20 stycznia 2009 r., sygn. P 4-/07.

32 Artykuł 119e ustawy Ordynacja podatkowa uchylony w dniu 1 stycznia $2019 \mathrm{r}$. przez Ustawę z dnia 23 października 2018 r. o zmianie ustawy o podatku dochodowym od osób fizycznych, ustawy o podatku dochodowym od osób prawnych, ustawy - Ordynacja podatkowa oraz niektórych innych ustaw (Dz.U. z 2018 r., poz. 2193).

33 Wyrok TK z dnia 23 kwietnia 2013 r., sygn. P 44/10, LEX nr 1311514. 
Konkludując powyższe rozważania, należy przyjąć, że w przedmiotowej sprawie zastosowanie nowej ustawy wprost nie miało charakteru retroaktywnego, ale wyłącznie retrospektywny. Następstwa zdarzeń prawnych zaistniałych przed wejściem w życie Klauzuli miały bowiem charakter ciągły i trwały także w okresie po wejściu w życie tych przepisów. Nie ma zatem przeszkód, by te następstwa prawne oceniać według norm „nowego prawa”34.

4.6.3. Ochrona praw słusznie nabytych

Refleksji należy poddać również to, czy bezpośrednie stosowanie ustawy nowej nie narusza praw słusznie nabytych przez Skarżących. Zasada ochrony tych praw jest bezpośrednio wywodzona z konstytucyjnej zasady demokratycznego państwa prawnego i jest uważana za jeden $\mathrm{z}$ najistotniejszych jej elementów ${ }^{35}$. Zakazuje ona arbitralnego znoszenia lub ograniczania praw podmiotowych przysługujących jednostce ${ }^{36}$. Odnosi się zarówno do praw publicznych, jak i prywatnych, nabytych in concreto lub in abstracto. Ma zastosowanie także do dostatecznie ukształtowanych ekspektatyw praw.

W stanie faktycznym przedmiotowej sprawy konieczne jest więc zidentyfikowanie, czy przed wejściem w życie Ustawy zmieniającej Skarżący nabyli jakieś prawo lub jego ekspektatywę wynikające z przepisów materialnych prawa podatkowego, które to Klauzula ogranicza lub znosi. Następnie natomiast należy rozstrzygnąć, czy Skarżący nabyli to prawo w sposób niewadliwy.

Na gruncie stanu faktycznego glosowanego orzeczenia trudno wskazać jakiekolwiek prawo podmiotowe wynikające $\mathrm{z}$ materialnych przepisów prawa podatkowego, które zostałoby ograniczone lub zniesione przez wprowadzenie przepisów 119a i n. o.p. Należy poddać głębszej refleksji, czy retrospektywne zastosowanie przepisów Klauzuli nie doprowadziło do zniesienia ekspektatywy prawa opodatkowania zysku wypracowanego przez C. ${ }^{1}$ sp. z o.o. (po przekształceniu w spółkę komandytową) na zasadach określonych w u.p.d.o.f. Niemniej ta koncepcja wydaje się wątpliwa z dwóch powodów.

Po pierwsze, Trybunał Konstytucyjny, definiując pojęcie ekspektatywy prawa, wskazał, że jest to „sytuacja prawna, w której zostały spełnione wszystkie zasadnicze przesłanki ustawowe nabycia określonych praw

\footnotetext{
34 Wyrok TK z dnia 31 marca 1998 r. sygn. K 24/97, LEX nr 31971.

35 Wyrok TK z dnia 29 stycznia 1992 r., sygn. K 15/91, LEX nr 25283.

36 Por. wyrok TK z dnia 10 grudnia 2007 r., sygn. P 43/07, LEX nr 321915.
} 
podmiotowych określonych przez prawo"37. W chwili wyrokowania nie została jednak zrealizowana główna przesłanka zastosowania u.p.d.o.f., czyli nie doszło do przekształcenia spółki kapitałowej w spółkę osobową. Trudno zatem zgodzić się ze stwierdzeniem, że po stronie Skarżących występowała ekspektatywa tego rodzaju.

Po drugie, należałoby poddać analizie, czy ewentualna ekspektatywa takiego prawa została nabyta przez Skarżących w sposób słuszny. Zarówno wypowiedzi Trybunału Konstytucyjnego, jak i doktryny w przedmiocie zasady ochrony praw słusznie nabytych cechują się dużym nagromadzeniem nieostrych pojęć. W wyroku z dnia 10 lutego 2015 r. ${ }^{38}$ Trybunał zwrócił uwagę, że „ochrona praw nabytych dotyczy praw, które zostały nabyte «słusznie», tzn. wyklucza to stosowanie analizowanej zasady w odniesieniu do praw nabytych contra legem i praeter legem oraz uzyskanych w sposób niedopuszczalny $\mathrm{w}$ demokratycznym państwie prawnym albo $\mathrm{z}$ naruszeniem zasady sprawiedliwości społecznej".

Gromadzenie zysków w spółce kapitałowej, a następne przekształcanie jej w spółkę osobową było powszechnie stosowanym schematem optymalizacji podatkowej. Bazował on na luce intra legem w przepisach u.p.d.o.f. ${ }^{39} \mathrm{~W} 2008$ r. ustawodawca podjął próbę jej usunięcia poprzez rozszerzenie katalogu dochodów z tytułu udziału w zyskach osób prawnych określonego w art. 24 ust. 5 u.p.d.o.f. ${ }^{40}$ Próba okazała się jednak nieudolna i nie wyeliminowała wspomnianego modelu optymalizacji podatkowej. Na gruncie przepisów materialnych prawa podatkowego czynności Skarżących należy zatem uznać za działania praeter legem. W świetle orzecznictwa Trybunału niemożliwe byłoby więc uznanie, że Skarżący nabyli w sposób niewadliwy ekspektatywę prawa do opodatkowania zysku spółki na uprzednio obowiązujących zasadach.

\section{WNIOSKI KOŃCOWE}

Konkludując rozważania, należy stwierdzić, że przyjęta przez Sąd wykładnia art. 7 Ustawy zmieniającej była błędna i nie mogła stanowić wyłącznego uzasadnienia zastosowania przepisów art. 119a i n. o.p. w stosunku do czynności Skarżących.

37 Wyrok TK z dnia 24 lutego 2010 r., sygn. K 6/09, LEX nr 560317.

38 Wyrok TK z dnia 10 lutego 2015 r., sygn. P 10/11, LEX nr 1640290.

${ }^{39}$ M. Jamroży, Przekształcenie spółki kapitałowej w spółkę osobowa - ucieczka przed podatkiem od dywidend?, „Przegląd Podatkowy” 2010, nr 4, s. 7-10.

40 Zob. druk sejmowy nr 1075/VI kadencja. 
Wypada przyjąć, że na gruncie stanu faktycznego przedmiotowej sprawy przepisy klauzuli przeciwko unikaniu opodatkowania znajdują zastosowanie. Niemniej w glosowanym wyroku brak prawidłowego uzasadnienia faktu dopuszczalności zastosowania tych przepisów wprost. Pomimo że sądy powszechnie przyjmują a priori, iż reguła intertemporalna „nakazuje stosowanie nowych rozwiązań dotyczących przeciwdziałania unikania opodatkowania również do spraw będących konsekwencją działań podjętych przed 15 lipca 2016 r.” ${ }^{41}$, nie można przychylić się do stanowiska, że stosowanie tych przepisów wprost w każdym stanie faktycznym z elementem dawnym jest dozwolone.

W mojej opinii nie jest konieczne, aby sądy czy organy podatkowe, które stosują klauzulę przeciwko unikaniu opodatkowania w aspekcie intertemporalnym, każdorazowo w uzasadnieniu analizowały wszystkie przesłanki oceny dopuszczalności retrospektywnego stosowania prawa. Oczywiście całkowicie prawidłowe jest przedstawienie ich w sposób łączny bądź w pewnych kombinacjach. Naturalnym zjawiskiem jest to, że ze względów ekonomiki procesowej w uzasadnieniach orzeczeń stosuje się różnorakie skróty myślowe. Pewne rozumowania logiczne przedstawiane są w formie syntetycznej. Niemniej jednak nie można się zgodzić z poglądem, że literalna treść przepisu art. 7 Ustawy zmieniającej stanowi wystarczającą podstawę do zastosowania przepisów Klauzuli do korzyści podatkowych uzyskanych w wyniku czynności dokonanych przed dniem nowelizacji. W każdej takiej sprawie Sąd powinien zbadać, czy zastosowanie przepisów klauzuli przeciwko unikaniu opodatkowania wprost nie stoi w sprzeczności z konstytucyjną zasadą demokratycznego państwa prawnego, na którą składają się zasada zaufania obywateli do państwa, zasada ochrony praw słusznie nabytych oraz zasada nieretroakcji prawa.

\section{BIBLIOGRAFIA}

Filipczyk H., Reguła intertemporalna klauzuli ogólnej przeciwko unikaniu opodatkowania w świetle standardów konstytucyjnych, „Przegląd Podatkowy” 2016, nr 9.

Gosiewski J., Pisemne uzasadnienie poprawki do art. 5 ustawy o zmianie ustawy - ordynacja podatkowa oraz niektórych innych ustaw, materiały sejmowe (niepubl.).

Jamroży M., Przekształcenie spółki kapitałowej w spółkę osobowa - ucieczka przed podatkiem od dywidend?, „Przegląd Podatkowy” 2010, nr 4.

41 Zob. Wyrok WSA w Warszawie z dnia 13 marca 2018 r., sygn. III SA/Wa 790/17, LEX nr 2614132; wyrok WSA w Łodzi z dnia 26 kwietnia 2017 r., sygn. I SA/Łd 173/17, LEX nr 2297740; wyrok NSA z dnia 3 października 2018 r., sygn. II FSK 78/18, LEX nr 2610573. 
Kancelaria Sejmu, Pełen zapis przebiegu posiedzenia Komisji Finansów Publicznych (nr 56) z 12 maja 2016 r., Biuletyn 611/VIII.

Kolibski M., Turzyński K., Reguła intertemporalna klauzuli ogólnej przeciwko unikaniu opodatkowania $w$ świetle standardów konstytucyjnych - polemika, „Przegląd Podatkowy" 2016, nr 12.

Kondej M., Problematyka intertemporalna stosowania klauzuli przeciwko unikaniu opodatkowania, „Przegląd Podatkowy” 2017, nr 7.

Lang W., Obowiązywanie normy prawnej w czasie w świetle logiki norm, Kraków 1960.

Łętowska E., O potrzebie zmiany poglądów na znaczenie art. 3 k.c., [w:] Studia z zakresu prawa gospodarczego i handlowego. Ksiegga pamiątkowa ku czci Profesora Stanisława Włodyki, red. W. Pyzioł i in., Kraków 1996.

Problematyka intertemporalna w prawie. Zagadnienia podstawowe. Rozstrzygnięcia intertemporalne. Geneza i funkcje, red. J. Mikołajewicz, Warszawa 2015.

\section{PARTIALly APPROVING COMMENTARY to the Regional Administrative Court in Warsaw JUDGMENT OF 8 JUNE 2018 (III SA/WA 2354/17)}

Summary. The gloss concerns the questionable problem of the application of the general antiavoidance rule in the inter-temporal aspect. The author of the gloss does not agree with the view presented in the ruling that the general anti-avoidance rule can always be applied also to the tax benefits achieved as a result of actions taken in the legal system before the amendment. Understanding the interim rule in this way may lead to the legal reclassification of the taxpayer's legal status in already closed legal situations. This view is incompatible with the constitutional principle of the non-retroactivity of law. In the author's opinion, in abstracto it is impossible neither to permit nor to exclude the application of the general anti-abuse rule to the actual state of affairs with the former element. Examination of the admissibility of the retrospective application of the provisions should be carried out ad causam based on specific facts.

Keywords: the general anti-abuse rule, tax, interim rule 